\title{
PENYULUHAN KESEHATAN TENTANG HIV/AIDS TERHADAP PENGETAHUAN DAN SIKAP PADA SISWA SMA NEGERI PARONGPONG DESA CIHANJUANG KECAMATAN BANDUNG BARAT
}

\author{
HEALTH EDUCATION TOWARDS KNOWLEDGE AND BEHAVIOR \\ ABOUT HIVIAIDS OF GOVERNMENT SENIOR HIGH SCHOOL \\ STUDENTS IN CIHANJUANG RAHAYU OF BANDUNG BARAT CITY
}

Imanuel Sri Mei Wulandari ${ }^{1}$, Irawati Namah ${ }^{2}$

Fakultas IImu keperawatan Universitas Advent Indonesia

E-mail: ari.imanuel@unai.edu

\begin{abstract}
Abstrak
Pendahuluan: Lebih dari setengah infeksi HIV didunia ditemukan pada usia 1519 tahun, dan mayoritas remaja terinfeksi karena hubungan seksual. Data Penularan HIV/AIDS pada remaja di Jawa Barat, dari jumlah penduduk Jawa Barat yang berusia $10-24$ tahun, sebesar 11.358 .704 atau $26,60 \%$ adalah remaja. Tujuan: Penelitian ini bertujuan untuk mengetahui pengetahuan dan sikap siswa SMA tantang HIV/AIDS di SMA Negeri Parompong Jawa Barat . Metode: Metode penelitian ini secara survey. Rancangan penelitian deskriptif pre- post tanpa kontrol dengan pendekatan cross sectional. Populasi kelas II SMA yang menjadi sampel sebanyak 86 orang yang terdiri dari IPA 34 siswa dan IPS 52 siswa . Instrumen penelitian untuk mengukur pengetahuan dan sikap berupa kuesioner tertutup dengan skala Guttman Instrument untuk perngukuraan tingkat pengetahuan dan sikap tentang HIV/AIDS. Analisa data dilakukan untuk mengetahui hubungan antara masing- masing variabel bebas (independent) dan variabel terikat (dependent) dengan uji paired t-test. Hasil: Terdapat pengaruh yang signifikan sebelum dan sesudah dilakukan penyeluhan kesehatan dengan nilai $p=0,000$. Diskusi: Dalam mencari informasi tentang HIV/AIDS diharapkan remaja lebih selektif baik melalui media cetak maupun media elektronik. Informas HIV/AIDS sebaiknya diberikan sejak dini, agar pengetahuan remaja tentang HIV/AIDS lebih baik.
\end{abstract}

Kata Kunci: HIV AIDS, Pengetahuan, Remaja

\begin{abstract}
Introduction: More than a half of HIV population in the World is found between the age of 15-19, and they are infected due to sex intercourse. West java populations age 10-24 are 11.358 .704 or equals to 26,60\%. Purpose: This study is aimed to assess knowledge and behavior of Government Senior High School Parongpong Students in Cihanjuang Rahayu of West Java. Method: Research methodology is survey. Research design is descriptive pre- post without control group and cross sectional approach. All Samples are 86 students of Government senior high school grade two. They are 34 from science division, and they are 53 from social division. The research instrument is close questioner which is graded with Guttmann scale. Data analysis is performed to assess the relationship between independent variable and dependant variable using paired T-test. Results: There is significant improvement on knowledge and behavior of Government Senior High School Parongpong Students after the health teaching session, which p score is 0,000. Discussion: In searching for information about HIVIAIDS, it is suggested that youth is properly select the printing and electronics as source of information. HIV/AIDS Health Education is suggested to be delivered since early youth, so that their knowledge and behavior on the subject is better.
\end{abstract}

Keywords: HIVIAIDS, Knowledge, Youth

JURNAL

\section{SKOLASTIK}

KEPERAWATAN

Vol, 5, No. 1 Januari - Juni 2019

ISSN: $2443-0935$

E-ISSN 2443 - 16990 


\section{PENDAHULUAN}

HIV adalah singkatan dari Human Immuno Deficiency Virus yang merupakan virus yang dapat menyebabkan penyakit AIDS. Virus ini menyerang manusia dan menyerang sistem kekebalan tubuh, sehingga tubuh menjadi lemah dalam melawan infeksi yang menyebabkan menurunnya system imun. AIDS merupakan singkatan dari Aquired Immune Deficiency Syndrome, Jadi AIDS adalah kumpulan gejala penyakit akibat menurunnya sistem kekebalan tubuh oleh virus yang disebut HIV jadi HIV/AIDS adalah suatu penyakit hingga saat ini belum dapat disembuhkan bahkan Penyakit HIV/AIDS ini merupakan masalah kesehatan masyarakat yang serius di seluruh dunia termasuk Indonesia. Yulianingsih, E. (2015).

Jumlah angka pengidap HIV/AIDS di dunia adalah 36,9 juta orang dari berbagai Negara. Penderita HIV tertinggi terdapat di kawasan Afrika Timur dan Afrika Selatan dengan angka 19,6 juta penderita dan di Indonesia terdapat 620.000, hal ini menempatkan bahwa Indonesia pada urutan ketiga penderita HIV/AIDS di dunia bahkan Indonesia juga sebagai negara dengan persebaran HIV/AIDS tercepat di dunia. kompas.com (2018).

\section{World Health Organization (WHO)} dan United Nations Proramme on HIV/AIDS (UNAIDS), dua organisasi dunia memperingatkan bahaya kepada 3 negara di Asia yang saat ini disebutsebut berada pada titik infeksi HIV. Kini diseluruh dunia diperkirakan lebih dari 41 juta orang yang mengidap HIV/AIDS. Sekitar $75 \%$ yang tertular HIV/AIDS berada dikawasan Asia Pastifik dan Afrika. Lebih dari 20 juta jiwa telah meninggal karena AIDS (WHO, 2015).

Menurut Kementrian Kesehatan Republik Indonesia (2018) Jumlah kumulatif infeksi HIV yang dilaporkan sampai dengan Juni 2018 sebanyak 301.959 jiwa $(47 \%$ dari estimasi ODHA jumlah orang dengan HIV AIDS tahun 2018 sebanyak 640.443 jiwa) dan paling banyak ditemukan di kelompok umur 25-49 tahun dan 20-24 tahun. Adapun provinsi dengan jumlah infeksi HIV tertinggi adalah DKI Jakarta (55.099), diikuti Jawa Timur (43.399), Jawa Barat (31.293), Papua (30.699), dan Jawa Tengah (24.757).

Kelompok remaja, yaitu penduduk dalam rentang usia 10-19 tahun, di Indonesia memiliki proporsi kurang lebih 1/5 dari jumlah seluruh penduduk. Ini sesuai dengan proporsi remaja di dunia dimana jumlah remaja diperkirakan 1,2 miliar atau sekitar 1/5 dari jumlah penduduk dunia Depkes, (2007) dalam Yani, (2017). Usia remaja merupakan usia yang sangat rentang untuk terinfeksi HIV. Lebih dari setengah infeksi HIV didunia ditemukan pada usia 15-19 tahun, dan mayoritas remaja terinfeksi karena hubungan seksual Guindo, (2014).

Jumlah remaja di Indonesia sebesar $17 \%$ dari seluruh penduduk Indonesia (Kementrian Kesehatan, 2017). Jumlah penduduk remaja di Provinsi Jawa Barat mencapai 11.358.704 jiwa atau sebesar 26,60\% dari total jumlah penduduk di Jawa Barat (Manurung, 2011). Jumlah remaja yang besar ini merupakan sumber daya yang besar untuk melaksanakan pembangunan untuk mewujudkan Jawa Barat maju dan sejahtera untuk semua sesuai dengan visi Pemerintah Daerah Jawa Barat. 
Kelompok remaja sangat rentan terhadap tiga risiko kesehatan reproduksi atau yang dikenal dengan triad KRR (Kesehatan Reproduksi Remaja) yaitu Seksualitas, Napza (Narkotika, Alkohol, Psikotropika dan Zat Adiktif Lainnya), serta HIV/AIDS.

Hasil Survei DKT Indonesia tahun 2005 juga menunjukkan bahwa remaja di beberapa wilayah Indonesia telah melakukan seks sebelum menikah, diantaranya Surabaya 54\%, di Bandung 47\% dan di Medan 52\%. Sementara itu, hasil Survei Kesehatan Reproduksi Remaja tahun 2012, bahwa remaja memiliki teman yang pernah berhubungan seksual dimulai dari usia 14-19 tahun, dengan wanita 0,7\% dan pria $4,5 \%$. Berdasarkan data tentang penyalahgunaan narkoba di Indonesia, $22 \%$ adalah siswa dan pelajar (BNN, 2014 dalam Yani, D. I. 2017). Data Penularan HIV/AIDS pada remaja di Jawa Barat, dari jumlah penduduk Jawa Barat yang berusia 10-24 tahun, sebesar 11.358.704 atau 26,60\% adalah remaja. Sebesar 3.147 remaja usia 15-29 tahun terkena HIV/AIDS dengan penularan terutama disebabkan melalui hubungan seks dan jarum suntik.

Provinsi Jawa Barat merupakan provinsi dengan kasus HIV/ AIDS terbanyak no 4 di Indonesia. Pangandaran sebagai salah satu kunjungan wisata bagi masyarakat Jawa Barat dan sekitarnya memiliki kasus HIV/ AIDS yang cukup tinggi. Yani, D. I. (2017).

Upaya untuk menurunkan kejadian HIV/IDS diantar remaja membutuhkan penanganan yang terintegrasi dan menyeluruh. Beberapa kegiatan untuk mengurangi HIV/AIDS diantaranya dengan pendidikan kesehatan.
Pendidikan kesehatan pada anak sekolah dapat dilakukan dengan memasukkan materi kesehatan ke dalam kurikulum pembelajaran. Sekolah sebagai institusi pendidikan mempunyai kesempatan yang luas sebagi tempat penyebaran informasi sehingga dapat meningkatkan sikap para remaja berkaitan dengan pencegahan dan penularan HIV/AIDS (Rahayuwati, 2008 dalam Handayani, S. (2016).

\section{TUJUAN}

Tujuan penelitian ini adalah untuk mengetahui tingkat pengetahuan dan sikap siswa SMA Negeri Parongpong sebelum dan sesudah melakukan penyeluhan.

\section{METODE PENELITIAN}

Metode penelitian ini secara survey. Rancangan penelitian deskriptif prepost tanpa kontrol dengan pendekatan cross sectional. Populasi pada penelitian ini adalah siswa SMA Negeri Parongpong yang menjadi sampel sebanyak 86 orang yaitu terdiri dari IPA 34 siswa dan IPS 52 siswa.

Instrumen penelitian untuk mengukur pengetahuan berupa kuesioner tertutup dengan skala Guttman. Kuesioner untuk mengukur sikap dengan menngunakan skala likert. Instrument untuk perngukuraan tingkat pengetahuan dan sikap tentang HIV/AIDS.

Analisa data dilakukan untuk mengetahui hubungan antara masingmasing variable bebas (independent) dan variabel terikat (dependent) dengan uji paired t-test. 


\section{HASIL PENELITIAN}

Hasil penelitian terhadap 86 responden diperoleh data bahwa $37,5 \%$ responden berusia 16 tahun, sebanyak $54,7 \%$ berusia 17 tahun dan sebanyak 3,49\% berusia 18 tahun. Mengambil jurusan IPA 39,5\% dan yang mengambil jurusan IPS $60,5 \%$, berjenis kelamain laki- laki dan perempuan. Dari hasil penelitian adanya perubahan dari sebelum dan sesudah dilakukan penyeluhan kesehatan tentang HIV/AIDS. Data pre-test menunjukan 68,14 dengan kategori (lebih dari cukup) dan setelah dilakukan penyeluhan kesehatan data post- test menunjukan 82,27 dengan kategori (baik) dan untuk sikap adanya perubahan dari sebelum dan sesudah dilakukan penyeluhan kesehatan. Data pre- test menunjukan 72,33 dengan kategori positif, dan setelah dilakukan penyeluhan kesehatan data post- test menunjukan 85 dengan kategori positif dalam pencegahan HIV/AIDS. Secara ringkas hasil penelitian dapat dilihat pada tabel 1.

Table 1. Data Demografi Responden

\begin{tabular}{lc}
\hline \multicolumn{1}{c}{ Karakteristik } & Persentase \\
\hline Jenis kelamin & \\
Laki- laki & $48,8 \%$ \\
Perempuan & $51,2 \%$ \\
& \\
\hline Usia & \\
& \\
16 & $37,5 \%$ \\
17 & $54,7 \%$ \\
18 & $3,49 \%$ \\
\hline Peminatan & \\
IPA & \\
IPS & $39,5 \%$ \\
& $60,5 \%$ \\
\hline
\end{tabular}

Dari tabel 1 dapat terlihat bahwa persentase responden pada laki- laki
$48,8 \%$ dan dari persentase perempuan $51,2 \%$. Usia responden di dominasi dengan usia 17 tahun yaitu 54,7 \%. Untuk peminat kelas responden pada kelas IPA 39,5 \% dan peminat kelas pada kelas IPS $60 \%$.

Table 2. Hasil Tingkat Pengetahuan

\begin{tabular}{cccc}
\hline Mean & $\begin{array}{c}\text { Std. } \\
\text { Deviation }\end{array}$ & Kategori \\
\hline Pre & 68,14 & 9,73 & $\begin{array}{c}\text { Lebih dari } \\
\text { cukup }\end{array}$ \\
Post & 82,27 & 9,50 & baik \\
\hline
\end{tabular}

Dari tabel 2 diatas dapat dilihat adanya perubahan dari sebelum dan sesudah dilakukan penyeluhan kesehatan. Data pre- test menunjukan 68,14 dengan kategori (lebih dari cukup) dan setelah dilakukan penyeluhan kesehatan data post- test menunjukan 82,27 dengan kategori (baik).

Table 3. Hasil Sikap

\begin{tabular}{lccc}
\hline & Mean & $\begin{array}{c}\text { Std. } \\
\text { Deviation }\end{array}$ & Kategori \\
& & & \\
\hline Pre- test & 72,33 & 3,3 & Positif \\
Post- test & 85 & 9,50 & Positif \\
& & & \\
\hline
\end{tabular}

Dari tabel 2 diatas dapat dilihat adanya perubahan dari sebelum dan sesudah dilakukan penyeluhan kesehatan. Data pre- test menunjukan 72,33 dengan kategori positif, dan setelah dilakukan penyeluhan kesehatan data post- test menunjukan 85 dengan kategori positif. 
Table 4. Pengaruh Penyeluhan Kesehatan

\begin{tabular}{llll}
\hline & $\begin{array}{l}\text { Pre- } \\
\text { test }\end{array}$ & $\begin{array}{l}\text { Post } \\
\text { - test }\end{array}$ & $\begin{array}{l}\text { Nilai } \\
\boldsymbol{p}\end{array}$ \\
\hline Pengetahua & 68.1 & 82.2 & 0,00 \\
n & 4 & 7 & 0 \\
Sikap & 72.3 & 85 & 0,00 \\
& 3 & & 0 \\
\hline
\end{tabular}

Dari table 4 terdapat pengaruh penyeluhan kesehatan tentang HIV/AIDS dengan nilai $p=0,000(p<$ $0,005)$, yang artinya terdapat pengaruh yang signifikan sebelum dan sesudah dilakukan penyuluhan kesehatan terhadap responden terhadap tingkat pengetahuan dan sikap responden terhadap HIV AIDS.

\section{PEMBAHASAN}

Siswa SMA Negeri Parongpong Bandung mempunyai pengetahuan baik tentang HIV/AIDS. Pengetahuan merupakan sesuatu yang diketahui, dan ini terjadi setelah melakukan pengindera terhadap suatu objek tertentu. Pengetahuan seseorang tentang objek mengandung dua aspek yaitu aspek positif dan aspek negatif. Kedua aspek ini yang akan menentukan sikap seseorang, semakin banyak aspek positif dari objek yang diketahui maka akan menimbulkan sikap makin positif terhadap objek tertentu. Faktor yang mempengaruhi tingkat pengetahuan adalah usia, jenis kelamin, pendidikan, lingkungan, budaya, sumber informasi. Desi, C. (2016).

Pengetahuan responden tentang HIV/AIDS adalah kemampuan responden menjawab pertanyaan yang diberikan yaitu tentang pengertian, penyebab, tanda dan gejala serta penularan dan pencegahan HIV/AIDS.
Bila dilihat sikap, siswa SMA Negeri Parongpong Bandung Barat, mempunyai sikap yang positif tentang HIV/AIDS. Sikap merupakan reaksi atau respon yang masih tertutup terhadap suatu stimulus atau objek menifestasi dari sikap tidak dapat dilihat langsung tetapi hanya dapat ditafsirkan terlebih dahulu dari perilaku yang tertutup. Desi, C. (2016). Perilaku yang didasari oleh pengetahuan akan lebih efektif dari pada perilaku yang tidak didasari oleh pengetahuan.

Pengetahuan dapat diperoleh dari pengalaman dan informasi yang pernah diamati seseorang terhadap suatu objek, artinya bahwa remaja yang mendapatkan informasi akan dapat membentuk pengetahuan baru sehngga akan menimbulkan kesadaran, pemahaman dan akhirnya berperilaku sesuai dengan pengetahuan yang dimilikinya. Menurut Notoatmodjo (2007), dalam Yulianingsih (2015). Penelitian ini sesuai dengan, Handayani, S. (2016), bahwa ada hubungan antara pengetahuan dan sikap remaja tentang pencegahan HIV/AIDS. Adanya perubahan dari sebelum dan sesudah dilakukan penyeluhan kesehatan. Data pre- test menunjukan 68.14 dengan kategori (lebih dari cukup), dan setelah dilakukan penyeluhan kesehatan data post- test menunjukan 82.27 dengan kategori (baik) dan untuk sikap adanya perubahan dari sebelum dan sesudah dilakukan penyeluhan kesehatan. Data pre- test menunjukan 72.33 dengan kategori positif, dan setelah dilakukan penyeluhan kesehatan data post- test menunjukan 85 dengan kategori positif. dapat disimpulkan bahwa ada hubungan antara pengetahuan dengan sikap remaja tentang HIV/AIDS. Semakin baik pengetahuan semakin 
baik pula sikap remaja tentang HIV/AIDS.

\section{KESIMPULAN DAN SARAN}

\section{Kesimpulan}

Ada hubungan pengetahuan dan sikap siswa SMAN tentang HIV/AIDS di SMA Negeri Parongpong.

\section{Saran}

a. Bagi Orang tua Diharapkan bagi orangtua untuk lebih memperhatikan dan mendidik anakanaknya dengan baik agar tidak mudah terpengaruh dengan orang lain khususnya pengaruh yang negatif

b. Bagi remajaDalam mencari informasi tentang HIV/AIDS diharapkan remaja lebih selektif baik melalui media cetak maupun media elektronik

c. Bagi institusi pendidikan Institusi hendaknya bekerja sama dengan instansi terkait atau tenaga kesehatan untuk memberikan informasi tentang HIV/AIDS kepada remaja

1 Informas HIV/AIDS sebaiknya diberikan sejak dini, agar pengetahuan remaja tentang HIV/AIDS lebih baik.

2 Memberikan materi tentang HIV/AIDS kepada para siswa, misalnya dengan cara memperlihatkan video/ menjelaskan pelajaran tentang kasus HIV/AIDS yang terjadi pada remaja dan juga menjelaskan penyebab terjadinya HIV/AIDS, serta memasang gambar, poster ataupun pamflet tentang HIV/AIDS dilingkungan sekolah.

\section{DAFTAR PUSTAKA}

Ayuningsih, N., Rondonuwu, R., \& Mulyadi, N. (2014). Pengaruh Penyuluhan tentang HIV/AIDS terhadap Pengetahuan dan Sikap Siswa di SMA Negeri 1 Manado. JURNAL KEPERAWATAN, 2(2).

Yulianingsih, E. (2015). Faktor-Faktor yang Berhubungan dengan Tindakan Berisiko Tertular HIV/AIDS pada Siswa SMA Negeri Di Kota Gorontalo. JIKMU, 5(4).

Kompas.

https://lifestile.kompas.com/read/ 2018/12/01/124545720/hivaidsdalam-angka-369-juta-penderita25-persen-tak-menyadarinta

WHO, 2015. HIV/AIDS, Dalam Online:www.who.int/hiv/en daikses pada tanggal: 13 November 2016

Kemenkes. RI. 2018. Kementerian Kesehatan RI Direktorat Jenderal pencegahan dan Pengendalian Penyakit. Kuningan Jakarta Selatan.

Yani, D. I. (2017). GAMBARAN PENGETAHUAN DAN SIKAP TENTANG HIV/AIDS PADA REMAJA DI PANGANDARAN. Jurnal Pengabdian Kepada Masyarakat, 1(1).

$\begin{array}{lrr}\text { Handayani, } & \text { S. } & \text { (2016). } \\ \text { PENGETAHUAN } & \text { DAN } \\ \text { SIKAP } & \text { SISWA } & \text { SMA } \\ \text { TENTANG HIV/AIDS } & \text { DI } \\ \text { SMU NEGERI I } & \text { WEDI } \\ \text { KLATEN. MOTORIK } & \text { Jurnal }\end{array}$


Ilmu Kesehatan (Journal of Health Science), 6(12).

Kementrian Kesehatan (2017). Data dan Informasi Kesehatan: Profil Data Kesehatan 2016. Jakarta: Kemenkes RI.

Manurung. (2011). Membangun remaja jawa barat yang bebas dari masalah seksualitas, NAPZA dan HIV/ AIDS.

Guindo, O. M., Liu, A., \& Haba, K. (2014). Knowledge, Attitudes and Practices of Youth towards HIV/AIDS in Mali, West Africa. International Journal of Advanced Physiology and Allied Sciences, 2(1), 12-23.

Desi Chrismayanti. (2016). GAMBARAN PENGETAHUAN DAN SIKAP REMAJA KELAS $\mathrm{X}$ TENTANG HIV/AIDS DI SMA SANTO FRANSISKUS ASISI PONTIANAK TAHUN. Naskah publikasi

$\begin{array}{lr}\text { Handayani, } & \text { S. } \\ \text { PENGETAHUAN } & \text { DAN } \\ \text { SIKAP SISWA } & \text { SMA } \\ \text { TENTANG HIV/AIDS DI } \\ \text { SMU NEGERI I WEDI } \\ \text { KLATEN. MOTORIK Jurnal } \\ \text { Ilmu Kesehatan (Journal Of } \\ \text { Health Science), 6(12). }\end{array}$


